\title{
Glucocorticoid-induced Insulin Resistance
}

\author{
THE IMPORTANCE OF POSTBINDING EVENTS IN THE REGULATION OF \\ INSULIN BINDING, ACTION, AND DEGRADATION IN FRESHLY \\ ISOLATED AND PRIMARY CULTURES OF RAT HEPATOCYTES
}

\author{
Jose F. Caro and John M. Amatruda, Department of Medicine, Division of \\ Endocrinology and Metabolism, University of Rochester School of Medicine, \\ Rochester, New York 14642
}

\begin{abstract}
A B S T R A C T We have recently proposed that "down regulation" of the insulin receptor may be one of the many biological responses of a cell to insulin. In an attempt to further explore this hypothesis we have studied insulin action, binding, and degradation in freshly isolated hepatocytes from rats rendered insulin resistant by the administration of dexamethasone, 1.0 $\mathrm{mg} / \mathrm{kg}$ every other day, for 1 and $4 \mathrm{wk}$, and in dexamethasone-treated $(0.1 \mu \mathrm{M}$ for $24 \mathrm{~h})$ primary cultures of hepatocytes from normal rats.

Dexamethasone treatment for 1 and 4 wk resulted in significant hyperinsulinemia and euglycemia when compared with age- and weight-matched control animals. Freshly isolated hepatocytes from rats treated with dexamethasone for $1 \mathrm{wk}$ bound less insulin than cells from control animals. This decrease in insulin binding was reflected in a decrease in the total number of cellular insulin receptors upon solubilization of the cells. Insulin action was evaluated by the ability of insulin to stimulate the uptake of $\alpha$-aminoisobutyric acid. The basal rate of aminoisobutyrate uptake in freshly isolated hepatocytes was enhanced by 1 wk of dexamethasone treatment, and although there was an apparent shift to the right in the dose-response curve for insulin-stimulated aminoisobutyrate uptake, at no insulin concentration was there a significant difference in the uptake by hepatocytes from control and dexamethasone-treated animals. This was true whether expressed as a percentage or absolute increment above basal. Insulin degradation was enhanced in hepatocytes from animals treated with dexamethasone for 1 wk but could not account for the observed changes in insulin binding.
\end{abstract}

Received for publication 20 April 1981 and in revised form 21 October 81 .
Hepatocytes from animals treated with dexamethasone for 4 wk were resistant to insulin with regard to aminoisobutyrate uptake, yet both insulin binding and insulin degradation returned to the levels observed in hepatocytes from control animals.

Primary cultures of hepatocytes from normal rats exposed to dexamethasone, $0.1 \mu \mathrm{M}$, in vitro for $24 \mathrm{~h}$ were similar to hepatocytes from rats treated with dexamethasone for $4 \mathrm{wk}$ in that they were insulin resistant with regard to aminoisobutyrate uptake and had normal to increased insulin binding. Insulin degradation was also similar. These cells were resistant to the ability of insulin, $0.1 \mu \mathrm{M}$, to down regulate its receptor whereas parallel cultures treated with insulin in the absence of dexamethasone had a $52 \%$ decrease in insulin binding.

These data indicate that hepatocytes that are insulin responsive respond to in vivo hyperinsulinemia by a decrease in the number of insulin receptors and by increased insulin degradation. Hepatocytes rendered resistant to insulin both in vivo and in vitro are resistant to these effects of insulin. These studies emphasize the importance of postbinding events in the modulation of insulin binding, action, and degradation, and support the hypothesis that down regulation of the hepatocyte insulin receptor is one of the many biological actions of insulin. They also help explain how a cell can be insulin resistant and have a normal number of insulin binding sites in the presence of hyperinsulinemia.

\section{INTRODUCTION}

An inverse relationship between insulin binding to target tissues and the concentration of hormone to which cells are exposed has been observed in some human 
metabolic states (1-3), animal disease models $(4,5)$, and in vitro cell systems (6-10). Such down regulation has been implicated in the development of insulin resistance in hyperinsulinemic states. There are, however, many insulin-resistant states that are associated with elevated circulating insulin levels and normal insulin binding (11-21). These exceptions indicate that the mechanism(s) of down regulation may be more complex than previously thought.

Although the specific mechanism(s) involved in down regulation of the insulin receptor by insulin are unknown, we have recently proposed that this may be one of the many biological responses of a cell to insulin (6). Evidence for this includes the ability of agents that mimic the effects of insulin without interacting with the insulin binding site to down regulate the insulin receptor (6), the inability of insulin to down regulate the insulin receptor of turkey erythrocytes, a cell that lacks active macromolecular synthesis (22), and the demonstration that cellular ATP levels may regulate insulin binding (23). The implications of these observations are that if a cell were resistant to some effects of insulin it might also be resistant to the ability of insulin to down regulate its receptor. Such an effect could be classified as an example of postbinding insulin resistance.

In an attempt to further explore this hypothesis we have studied insulin action, binding, and degradation in freshly isolated hepatocytes from rats made resistant to insulin by the administration of glucocorticoids for 1 and $4 \mathrm{wk}$. In addition, we have studied the effects of glucocorticoids on insulin binding, action, and degradation when added in vitro to primary cultures of hepatocytes from normal rats. The data demonstrate the importance of postbinding events in the modulation of insulin action, binding, and degradation in the liver and suggest that a hepatocyte must be insulin responsive for insulin to down regulate its receptor.

\section{METHODS}

Chemicals. Alpha-[ $\left[1^{14} \mathrm{C}\right]$-aminoisobutyric acid $(51.6 \mathrm{mCi} /$ $\mathrm{mmol}$ ), carrier-free $\mathrm{Na}{ }^{125} \mathrm{I}$, (methoxy $\left.{ }^{3} \mathrm{H}\right)$ inulin $(186.4 \mathrm{mCi}$ / g), and 3-0-[methyl $\left.-{ }^{14} \mathrm{C}\right]-\mathrm{D}-$ glucose $(58.0 \mathrm{mCi} / \mathrm{mmol})$ were obtained from New England Nuclear, Boston, MA. Crude collagenase (CLS II 48H141, $1.52 \mathrm{U} / \mathrm{mg}$ ) was obtained from Worthington Biochemical Corp., Freehold, N. J.; fraction V bovine albumin from Reheis Chemical Co., Chicago, IL; $\alpha$-aminoisobutyric acid from Calbiochem-Behring Corp., American Hoechst, San Diego, CA; and serum-free medium (Waymouth MB 752/1) from Gibco Laboratories, Grand Island Biological Co., Grand Island, NY. Crystalline porcine insulin was kindly provided by Dr. Ronald Chance of Eli Lilly \& Co., Indianapolis, IN.

Protocol. Male Sprague-Dawley rats fed ad lib. with initial weights of $160-170 \mathrm{~g}$ were used for all experiments. The study consisted of two experimental groups: group I, which received dexamethasone $(1 \mathrm{mg} / \mathrm{kg})$ intramuscularly every
$48 \mathrm{~h}$ for $1 \mathrm{wk}$, and group II, which received the same dosage schedule for $4 \mathrm{wk}$. Control animals for each group received an equivalent volume of saline intramuscularly every $48 \mathrm{~h}$ for 1 and 4 wk.

Preparation of hepatocytes. The liver perfusion and the isolation and suspension of hepatocytes were performed as described (5) with the exception that for insulin binding and degradation the cells were suspended at 0.8-1.2 $\times 10^{6}$ cells/ $\mathrm{ml}$, and both binding and degradation were assessed at $25^{\circ} \mathrm{C}$.

Primary cultures of hepatocytes were performed as described (6). When present, insulin $(0.1 \mu \mathrm{M})$ and dexamethasone $(0.1 \mu \mathrm{M})$ were added at the time of the first medium change $4 \mathrm{~h}$ after plating. Insulin was readded every $8 \mathrm{~h}$. After $24 \mathrm{~h}$ of culture the cells were washed as described (6) in Hanks'-HEPES buffer, pH 7.4, containing glucose (8 $\mathrm{mM})$ and bovine serum albumin $(10 \mathrm{mg} / \mathrm{ml})$. Insulin action is assessed in the same buffer at $37^{\circ} \mathrm{C}$ and insulin binding and degradation at $25^{\circ} \mathrm{C}$.

Binding of ${ }^{125}$ I-labeled insulin. Insulin was iodinated with chloramine $\mathrm{T}$ according to the method of Cuatrecasas (24) and insulin binding assessed as described $(5,6)$. Nonspecific binding is $<10 \%$ in all cell groups. Maximum insulin binding is achieved at $15-30 \mathrm{~min}$ and is maintained for 60 $90 \mathrm{~min}(25,26)$. All binding data reported were obtained at $45 \mathrm{~min}$.

In some studies hepatocytes were solubilized overnight at $4^{\circ} \mathrm{C}$ with constant stirring in Hanks'-HEPES buffer, pH 7.4, containing $10 \mathrm{mg} / \mathrm{ml}$ bovine serum albumin, $1 \%$ Triton $\mathrm{X}$ 100 , and $1 \mathrm{mM} N$-ethylmaleimide. The solubilized cells are centrifuged at $48,000 \mathrm{~g}$ for $30 \mathrm{~min}$ and the supernatant diluted 1:10 with the above buffer without Triton X-100. Aliquots of the supernatant containing the solubilized insulin receptor are incubated at $25^{\circ} \mathrm{C}$ for $45 \mathrm{~min}$ with ${ }^{125} \mathrm{I}$-labeled insulin, $0.1 \mathrm{nM}$, plus increasing concentrations of unlabeled insulin. The bound insulin and added bovine gamma globulin are precipitated with $12.5 \%$ polyethylene glycol at $4^{\circ} \mathrm{C}$ (27). ${ }^{125} \mathrm{I}$-labeled insulin is purified on a Bio-Gel (Bio-Rad Laboratories, Richmond, CA) P-30 column immediately before use. Nonspecific binding, which is the amount of ${ }^{125} \mathrm{I}$ labeled insulin $(0.1 \mathrm{nM})$ bound in the presence of unlabeled insulin $(1 \mu \mathrm{M})$, is $27 \pm 3 \%$ of total insulin binding at tracer concentrations of ${ }^{125} \mathrm{I}$-labeled insulin $(0.1 \mathrm{nM})$. In these experiments the data is normalized by the number of cells extracted.

Insulin degradation studies. The degradation of ${ }^{125} \mathrm{I}-\mathrm{la}-$ beled insulin in the medium was determined by precipitation with trichloroacetic acid after a 45-min incubation of hepatocytes with ${ }^{125} \mathrm{I}$-labeled insulin, $0.1 \mathrm{nM}$, plus increasing concentrations of unlabeled insulin at $25^{\circ} \mathrm{C}(25)$. The leakage of degradative enzymes into the medium accounts for $<1 \%$ of the total degradation observed in freshly isolated and primary cultures of hepatocytes under the conditions of these studies $(25,26)$. The nature of the ${ }^{125}$ I associated with the cells is determined by solubilization of the hepatocytes in $4 \mathrm{M}$ urea, $1 \mathrm{M}$ acetic acid, and $0.1 \%$ Triton $\mathrm{X}-100$ followed by chromatography on Sephadex G-50 as reported (25).

Aminoisobutyric acid $(A I B)^{1}$ uptake. To measure AIB uptake freshly isolated and primary cultures of hepatocytes were incubated in Hanks'-HEPES buffer, pH 7.4, containing $8 \mathrm{mM}$ glucose in the absence and presence of varying concentrations of insulin for $2 \mathrm{~h}$ at $37^{\circ} \mathrm{C}$ as reported by LeCam et al. (28). Following this preincubation, $\left[{ }^{14} \mathrm{C}\right] \mathrm{AIB}(0.1 \mathrm{mM}$, $1.4 \mathrm{mCi} / \mathrm{mmol}$ ) was added. Uptake is linear for at least 20

${ }^{1}$ Abbreviations used in this paper: AIB, aminoisobutyric acid; Dex, dexamethasone. 
min in both cell systems, and therefore the reaction was terminated at $10 \mathrm{~min}$ to obtain initial rates of uptake. For freshly isolated hepatocytes uptake was terminated by the oil separation method as reported (5). For primary cultures of hepatocytes the plates were washed with ice-cold phosphate-buffered saline, $\mathrm{pH} 7.4$, and the cells were scraped off the plates and centrifuged through oil as for freshly isolated hepatocytes.

Cell counting and sizing. Freshly isolated hepatocytes were counted in a hemocytometer. For primary cultures of hepatocytes cell number was estimated by protein determination (6). The quantity of protein per plate was $1.08 \pm 0.02$ and $0.91 \pm 0.02 \mathrm{mg}$ for control and dexamethasone-treated cells, respectively. Cell size was estimated by determining the intracellular water space using 3-O-[methyl- $\left.{ }^{14} \mathrm{C}\right]-\mathrm{D}-\mathrm{glu}-$ cose and adjusting for the trapping of extracellular water by inulin space measurement as reported. (5).

All statistical analyses were performed by the unpaired Student's $t$ test. Data are expressed as the mean $\pm \mathrm{SE}$.

\section{RESULTS}

In vivo effects of 1 wk of dexamethasone treatment on insulin binding and action in freshly isolated hepatocytes. Animals receiving dexamethasone for $1 \mathrm{wk}$ (group I Dex) weighed $188 \pm 11 \mathrm{~g}(n=6)$, which is similar to that of the age- and weight-matched control animals $(199 \pm 12 \mathrm{~g}, n=6)$. The size of the isolated hepatocytes as assessed by water space was also similar and was $4.0 \pm 0.8$ and $3.9 \pm 0.9 \mu \mathrm{l}$ cell water $/ 10^{6}$ cells for group I Dex and control animals, respectively. Serum insulin levels, however, were significantly higher in the group I Dex animals $(60 \pm 4 \mu \mathrm{U} / \mathrm{ml})$ than in the control rats $(36 \pm 10 \mu \mathrm{U} / \mathrm{ml}, P<0.01)$. The elevated serum insulin levels in the presence of similar serum glucose levels $(228 \pm 13$ and $205 \pm 8 \mathrm{mg} / 100 \mathrm{ml}$ in group I Dex and control animals, respectively) are suggestive of an insulin-resistant state induced by dexamethasone. Because the rats were fed overnight, these glucose values represent postprandial values.

A comparison of freshly isolated hepatocytes from group I Dex and control animals with respect to insulin binding and insulin action is illustrated in Fig. 1. Because the control animals for the rats receiving dexamethasone for 1 and $4 \mathrm{wk}$ had identical insulin binding as well as basal and insulin-stimulated AIB uptake, the results were combined into one group. This similarity is consistent with our previous data that demonstrated that body weight from a mean of 209-414 $\mathrm{g}$ was without effect on insulin binding or insulin-stimulated AIB uptake in freshly isolated hepatocytes (5).

Hepatocytes from group I Dex animals have an increased basal rate of AIB uptake $\left(31.4 \pm 1.3 \mathrm{pmol} / 10^{6}\right.$ cells per min) compared with hepatocytes from control animals $\left(19.7 \pm 1.3 \mathrm{pmol} / 10^{6}\right.$ cells per min, $\left.P<0.001\right)$. Because these different basal rates of AIB uptake can complicate the interpretation of a cell's responsiveness to insulin, we will define resistance as a condition in which maximal concentrations of insulin evoke a sub-
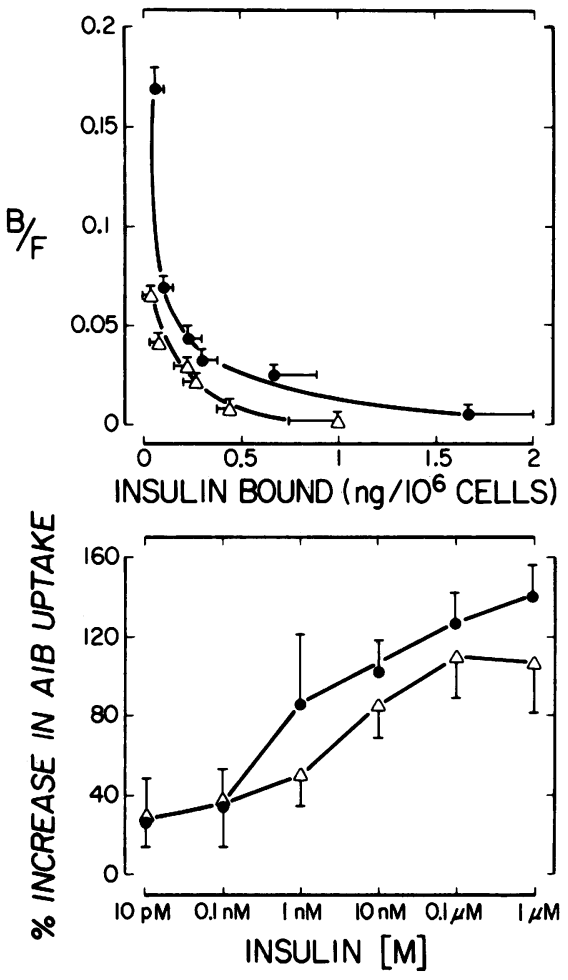

FIGURE 1 Upper panel: Scatchard analyses of insulin binding to freshly isolated hepatocytes from control animals $(0)$ and those treated with dexamethasone for $1 \mathrm{wk}(\Delta)$. Lower panel: Dose-response curves for the insulin-stimulated uptake of aminoisobutyrate. The conditions of cell isolation and measurement of insulin binding and AIB uptake are described in Methods. The data represent the mean $\pm S E$ of triplicate determinations of from three to five separate experiments in each group.

maximal response in both the percentage increase and absolute increment in AIB uptake above basal.

The dose-response curves for insulin-stimulated AIB uptake are illustrated in Fig. 1 (bottom panel). Hepatocytes from control and group I Dex animals respond significantly to insulin at insulin concentrations from $0.1 \mathrm{nM}$ to $1 \mu \mathrm{M}(P<0.05$ to $P<0.001)$. In both states the maximal stimulation by insulin was achieved at hormone concentrations of $0.1 \mu \mathrm{M}-1 \mu \mathrm{M}$. From these curves, the concentrations of insulin that elicit a half-maximal stimulation of AIB uptake $\left(\mathrm{ED}_{50}\right)$ are 0.7 and $1.5 \mathrm{nM}$ for hepatocytes from control and group I Dex animals, respectively. At no insulin concentration, however, is there a significant difference between the two curves. This is true whether the data is expressed as a percentage increase or absolute increment above basal. Thus, hepatocytes from group I Dex animals are not resistant to insulin with regard to AIB uptake, i.e., the maximal response to insulin is normal. Furthermore, although hepatocytes from these ani- 
mals appear to be less sensitive to insulin, this did not achieve statistical significance.

Hepatocytes from rats receiving dexamethasone for $1 \mathrm{wk}$ bound an average of $71 \pm 20 \%$ less insulin than those from control animals at insulin concentrations from $0.1 \mathrm{nM}$ to $0.1 \mu \mathrm{M}$ (Fig. 1). This difference was significant at insulin concentrations of $0.1 \mathrm{nM}$ to $5 \mathrm{nM}$ $(P<0.05-P<0.001)$. Because of the experimental error at higher concentrations of insulin, there is no statistically significant difference in insulin binding to hepatocytes from control and group I Dex animals at insulin concentrations of $10 \mathrm{nM}$ and $0.1 \mu \mathrm{M}$. An analysis of the average affinity by the method of DeMeyts and Roth (29) indicates that at the lowest receptor occupancy $\left(B / R_{o}=2-5 \%\right)$ hepatocytes from group I Dex animals have a $33 \%$ decrease in average affinity for insulin $(P<0.05)$. Whereas these data should be interpreted with caution because of the large experimental error in the determination of the $R_{o}$ value, the decrease in average affinity is consistent with the significant increase in the concentration of native insulin necessary to compete for $50 \%$ of the tracer ${ }^{125}$ I-labeled insulin specifically bound to cells from group I Dex animals $(1.5 \pm 0.4 \mathrm{nM}, n=3)$ as compared with cells from control animals $(0.36 \pm 0.05 \mathrm{nM}, n=4, P<0.05)$. Taken together, these data indicate that $1 \mathrm{wk}$ of dexamethasone treatment leads to a decrease in insulin binding due to a significant decrease in affinity of the insulin receptor for insulin and possibly also a decrease in the total number of available insulin binding sites.

The apparent decrease in receptor number is supported by the data in Fig. 2. Because there are specific intracellular binding sites for insulin (30), we investigated whether $1 \mathrm{wk}$ of dexamethasone treatment has an effect on the total number of cellular insulin binding sites. Freshly isolated hepatocytes from control and group I Dex animals were solubilized and insulin binding was analyzed as described in Methods. Fig. 2 is a Scatchard analysis of these data. The solubilized hepatocytes from group I Dex animals bind significantly less $(P<0.05$ to $P<0.02)$ insulin than cells from control rats at every insulin concentration used. This decrease in binding appears to be mainly due to a decrease in receptor number because there is no significant difference in average affinity (data not shown) and the concentration of insulin that competes for $50 \%$ of specific ${ }^{125}$ I-labeled insulin $(0.1 \mathrm{nM})$ binding is the same in the two groups of cells $(2.1 \mathrm{nM}$ for solubilized receptors from control animals and 1.9 $\mathrm{nM}$ for receptors from group I Dex animals). Interestingly changes in affinity are not observed in this assay as compared with the whole cell preparation where apparent affinity decreased in cells from group I Dex animals (Fig. 1). Because the majority of insulin binding sites are intracellular (Figs. 1, 2) it is possible

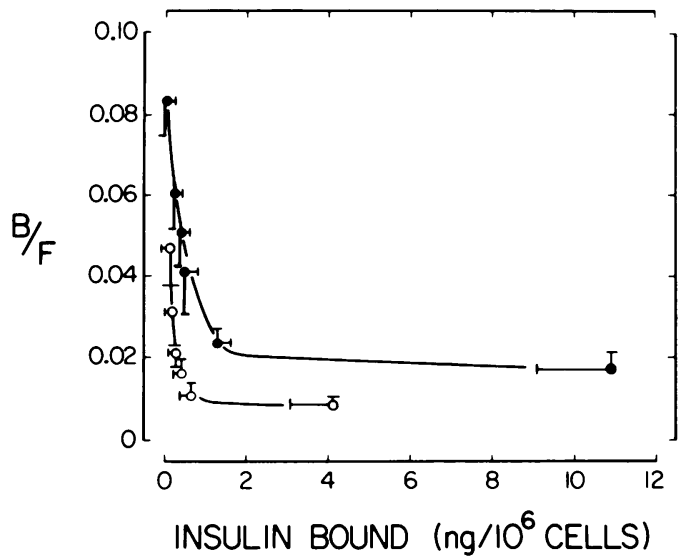

Figure 2 Scatchard analyses of insulin binding to the solubilized insulin receptor of freshly isolated rat hepatocytes from control (O) animals and animals treated with dexamethasone for 1 wk $(O)$. The conditions of cell isolation, solubilization of the insulin receptor, and measurement of insulin binding are described in Methods. The data represent the mean $\pm S E$ of triplicate determinations from three separate experiments in each group.

that regulatory changes in affinity occur only in the available binding sites on the plasma membrane. These changes may not be apparent when plasma membrane sites are diluted by the much larger intracellular pool of insulin binding sites. The decrease in affinity of the total cellular pool of insulin binding sites is especially evident when comparing the $\mathrm{B} / \mathrm{F}$ ratios of solubilized receptors (Fig. 2) to those of freshly isolated intact hepatocytes (Fig. 1) and the higher concentration of unlabeled insulin necessary to displace $50 \%$ of the tracer ${ }^{125}$ I-labeled insulin bound to solubilized as compared with intact cells from control animals. Taken together these data indicate that $1 \mathrm{wk}$ of dexamethasone treatment leads to a decrease in insulin binding due to a significant decrease in affinity of the available insulin receptors for insulin and a decrease in total number of cellular insulin binding sites.

In vivo effect of 4 wk of dexamethasone on insulin binding and action in hepatocytes. Animals receiving dexamethasone for 4 wk (group II Dex) were similar to control animals both in body weight $(252 \pm 24$ $\mathrm{g}, n=5$ and $305 \pm 20 \mathrm{~g}, n=4$, respectively) and hepatocyte size $\left(4.9 \pm 0.9\right.$ and $4.1 \pm 1.1 \mu$ l cell water $/ 10^{6}$ cells, respectively). In addition both groups of animals had similar serum glucose concentrations $(225 \pm 8$ and $246 \pm 25 \mathrm{mg} / 100 \mathrm{ml}$ in control and group II Dex animals, respectively). Serum insulin levels were significantly higher, however, in the group II Dex animals $(123 \pm 17 \mu \mathrm{U} / \mathrm{ml}$ and $77 \pm 9 \mu \mathrm{U} / \mathrm{ml}$ in group II Dex and control animals, respectively, $P<0.05$ ), again suggesting insulin resistance in this animal model.

Fig. 3 illustrates the Scatchard analyses of the insulin 

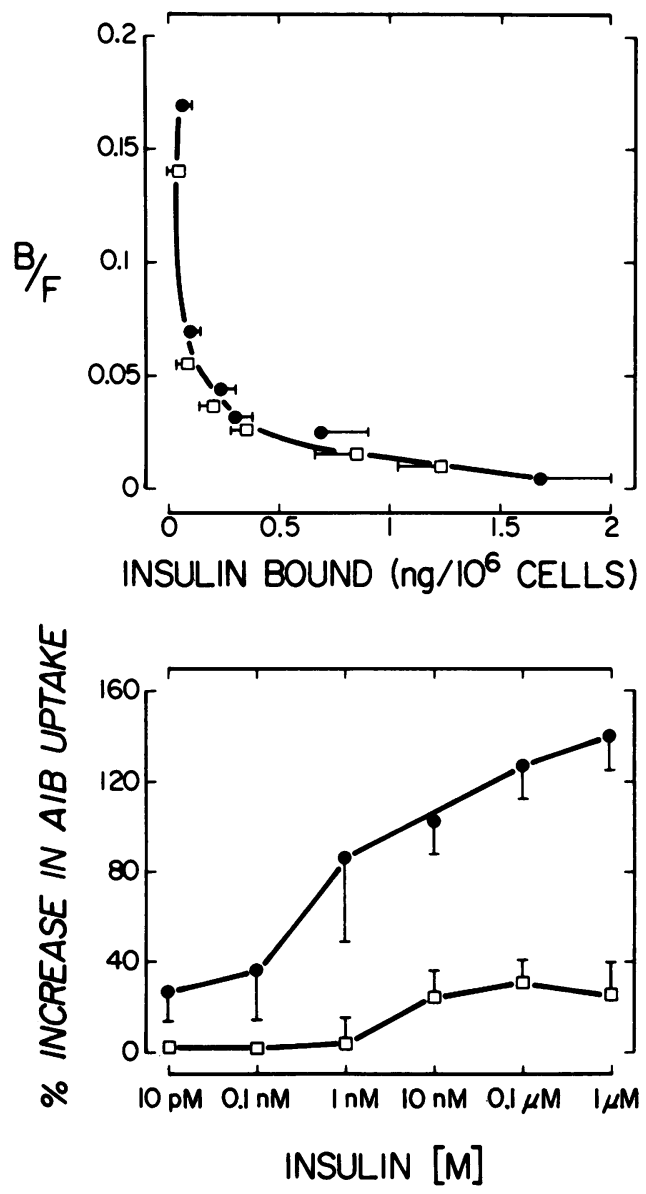

Figure 3 Upper panel: Scatchard analyses of insulin binding to freshly isolated hepatocytes from control animals (๑) and those treated with dexamethasone for $4 \mathrm{wk}$ (口). Lower panel: Dose-response curves for the insulin-stimulated uptake of aminoisobutyrate. The conditions of cell isolation and measurement of insulin binding and AIB uptake are described in Methods. The data represent the mean $\pm \mathrm{SE}$ of triplicate determinations of from three to five separate experiments in each group.

binding data in hepatocytes from control and group II Dex animals. There is no significant difference in insulin binding between the two groups of cells.

With regard to AIB uptake, hepatocytes from group II Dex animals had significantly greater basal rates of AIB uptake $\left(50.0 \pm 8.0 \mathrm{pmol} / 10^{6}\right.$ cells per $\left.\mathrm{min}\right)$ when compared with hepatocytes from control animals (see above, $P<0.01)$ but not when compared with cells from group I Dex animals. Fig. 3 (bottom panel) illustrates the dose-response curves for insulin-stimulated AIB uptake. Hepatocytes from group II Dex animals respond significantly to insulin $(P<0.05)$ only at insulin concentrations of $10 \mathrm{nM}$ and $0.1 \mu \mathrm{M}$. The $\mathrm{ED}_{50}$ for insulin in these cells is $5 \mathrm{nM}$ as compared to
$0.7 \mathrm{nM}$ in cells from control animals. Hepatocytes from control animals have a significantly greater insulin response at all insulin concentrations tested $(P<0.05-$ $P<0.001)$. This is true whether the data is expressed as a percentage or absolute increase in uptake above basal. Thus, hepatocytes from group II Dex animals demonstrate both a decreased responsiveness to insulin, i.e., insulin resistance and a shift to the right in the dose-response curve for insulin-stimulated AIB uptake, i.e. insulin insensitivity.

Insulin degradation studies. The percentage of ${ }^{125}$ I-insulin $(0.1 \mathrm{nM})$ degraded by cells from control, group I, and group II Dex animals is 16.2 \pm 1.7 , $22.1 \pm 3.4$, and $16.4 \pm 1.5$, respectively. This percentage decreased with increasing concentrations of unlabeled insulin and at $1 \mu \mathrm{M}$ the percentage of insulin degraded is $7.7 \pm 2,12.3 \pm 3.7$, and $7.4 \pm 4.7$, respectively. The hepatocytes from group I Dex animals degrade more insulin at every insulin concentration used, and the difference is significant $(P<0.05)$ at insulin concentrations of $10 \mathrm{nM}, 0.1 \mu \mathrm{M}$, and $1 \mu \mathrm{M}$. This is somewhat unexpected because these cells bind less insulin than the control cells and we (26) and others (31) have demonstrated that in hepatocytes insulin binding may be rate limiting for insulin degradation. The decrease in binding observed in cells from group I Dex animals $(71 \pm 20 \%)$ cannot, however, be explained by the small decrease $\left(7.4\right.$ to $7.1 \%$ ) in intact free ${ }^{125}$ I-labeled insulin present in the medium.

If the log of the velocity of total insulin degradation is plotted against the log of total insulin bound with no correction for nonspecific binding (Fig. 4), a linear relationship is found. This has been demonstrated in freshly isolated (31) and primary cultures (26) of hepatocytes from normal rats and suggests that degradation velocity is first order with respect to the total amount of insulin bound. In addition, this relationship suggests that all insulin binding sites, including those involved in nonspecific binding, may mediate insulin degradation (26). Thus, whereas the relationship between insulin binding and degradation is maintained in cells from group I Dex animals, there is more insulin degraded for a given amount of insulin bound.

To determine the nature of the ${ }^{125} \mathrm{I}$ associated with cells, hepatocytes from all groups of animals were solubilized as described in Methods and chromatographed on a column of Sephadex G-50. Fig. 5 demonstrates that the percentage of bound radioactivity that elutes with the second peak and coelutes with intact insulin is the same in the cells from control, group I, and group II Dex animals (72 $\pm 4.1,74.3 \pm 4.9$, and $71 \pm 7.4 \%$, respectively). Thus, even though the degradation velocity in the cells from group I Dex animals is increased, the percentage of degradation products retained by the cell at a given time is not 


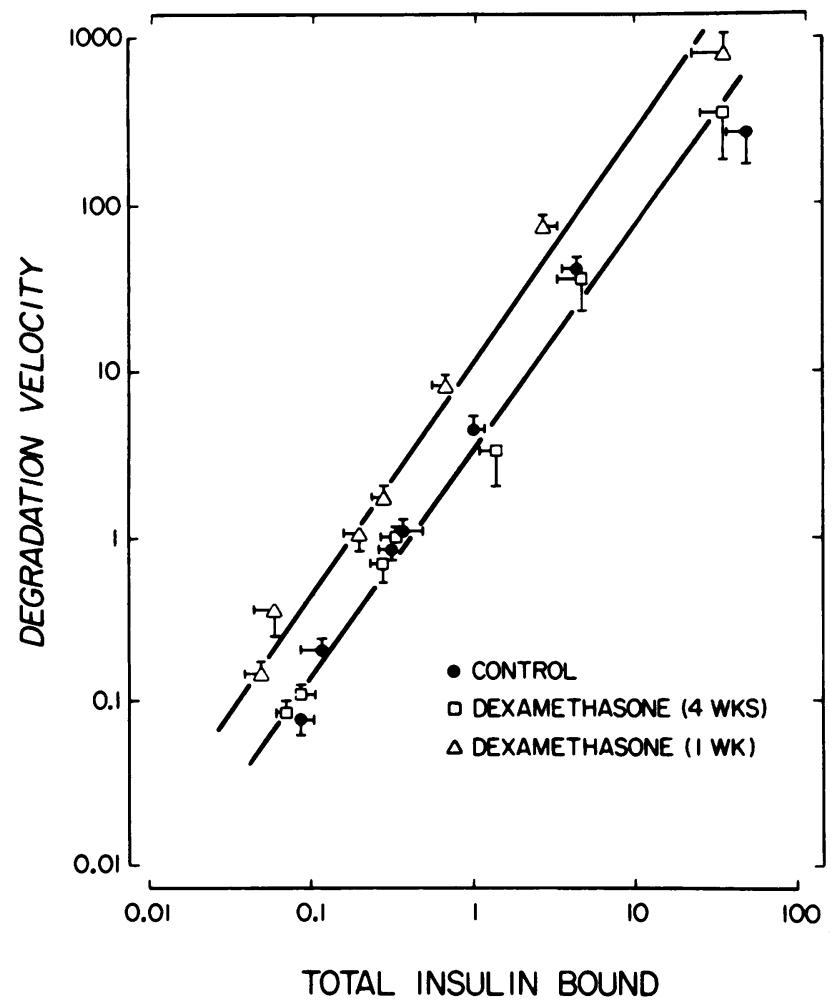

Figure 4 Degradation velocity (log) vs. the concentration of total insulin bound (log). Degradation velocity and the total insulin bound are expressed as nanograms $/ 10^{6}$ cells per $45 \mathrm{~min}$. The conditions of cell isolation and measurement of insulin degradation and binding are described in Methods. The data represent the mean $\pm S E$ of triplicate determinations from three separate experiments for each group.

increased. This suggests a more rapid disposal of these products into the medium.

In vitro effects of dexamethasone on insulin binding, action, and degradation in cultured hepatocytes. To assess the role of dexamethasone itself in the changes in insulin binding, action, and degradation that we observed in freshly isolated hepatocytes from dexamethasone-treated rats, we exposed primary cultures of hepatocytes from normal rats to a high concentration of dexamethasone, $0.1 \mu \mathrm{M}$ for $24 \mathrm{~h}$. Under these conditions hepatocytes treated with dexamethasone bind significantly more insulin than control cells at high concentrations of insulin $(10 \mathrm{nM}, P<0.05 ; 0.1$ $\mu M, P<0.001$ ) (Fig. 6). The concentration of native insulin that competes for $50 \%$ of the tracer ${ }^{125}$ I-labeled insulin specifically bound, however, is the same in both groups of cells $(0.43$ and $0.40 \mathrm{nM}$ for control and dexamethasone-treated cells, respectively) suggesting that the overall affinity of the insulin receptor for insulin is unchanged. Scatchard analyses of these binding data (Fig. 6) demonstrate an increase in the number of available insulin receptors in dexamethasone-treated cells with no change in the apparent affinity.

Insulin degradation at tracer concentration of hormone $(0.1 \mathrm{nM})$ is similar in both groups of cells with $9.0 \pm 1.7$ and $6.4 \pm 1.6 \%$ of the insulin degraded by control and dexamethasone-treated cells, respectively.

Although the basal rate of AIB uptake is not affected by dexamethasone $(59 \pm 20$ vs. $78 \pm 34 \mathrm{pmol} /$ plate per

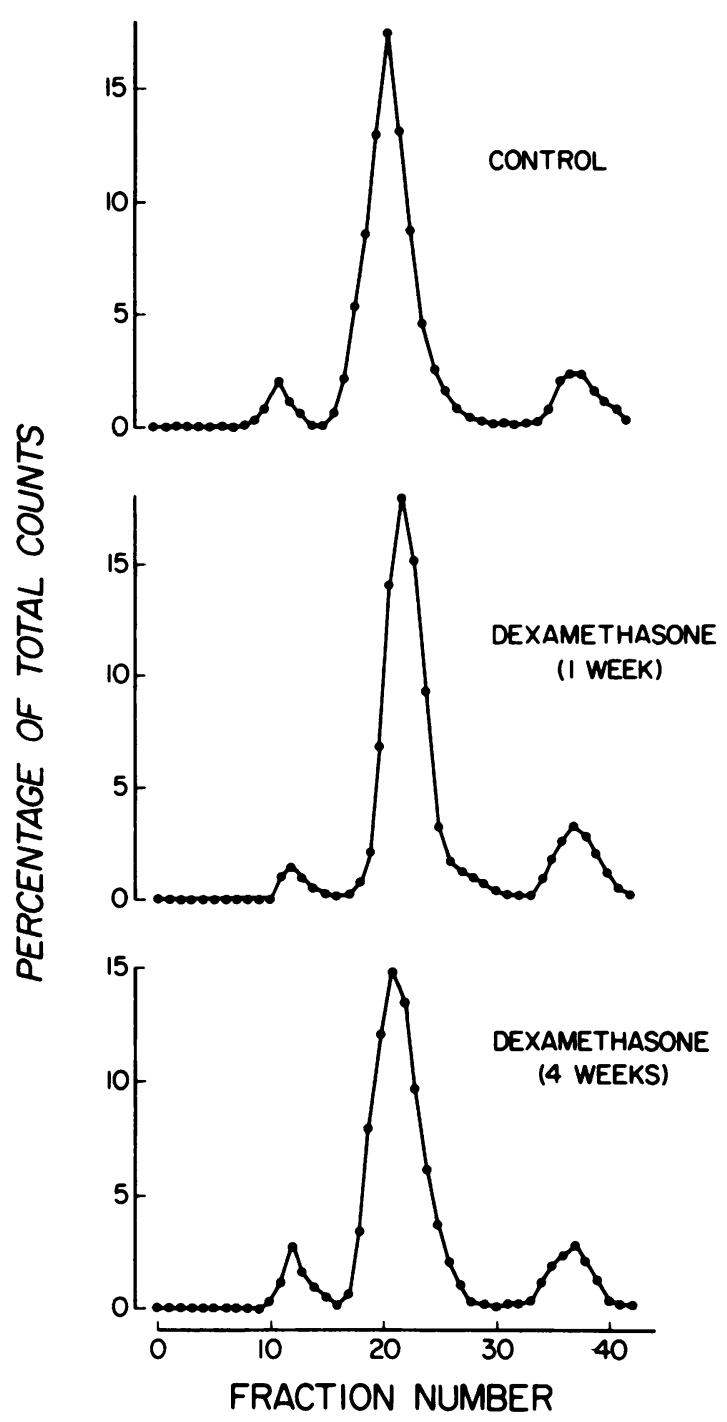

Figure 5 Gel filtration profiles of hepatocyte bound ${ }^{125} \mathrm{I}$ labeled insulin after 45-min incubations with ${ }^{125} \mathrm{I}$-labeled insulin $(0.1 \mathrm{nM})$. In each profile from left to right, the first peak represents material eluting in the void volume; the second peak intact insulin; and the third peak the final degradation products that coelute with $\mathrm{Na}{ }^{125} \mathrm{I}$. The conditions of cell isolation and measurement of insulin degradation are described in Methods. The figure illustrates a representative experiment. The mean of three separate experiments is given in the text. 

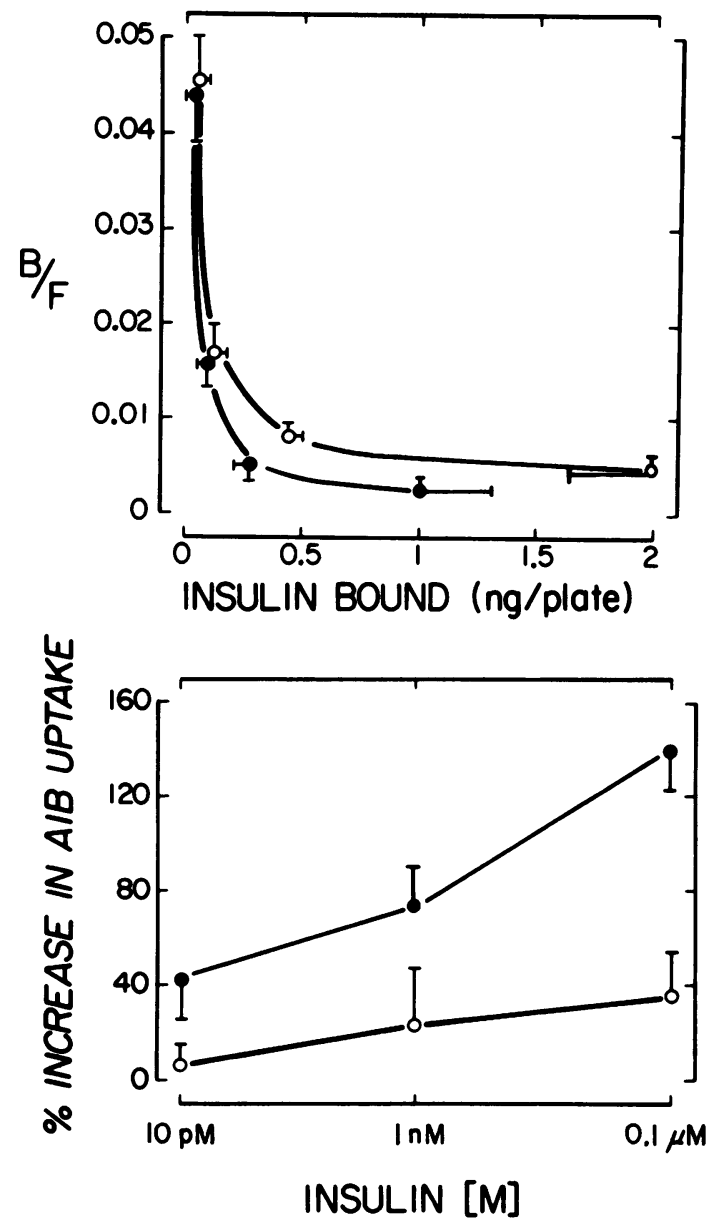

Figure 6 Upper panel: Scatchard analyses of the insulin binding data in primary cultures of rat hepatocytes cultured for $24 \mathrm{~h}$ in the absence $(0)$ and presence $(O)$ of dexamethasone, $0.1 \mu \mathrm{M}$. Lower panel: dose-response curves for the insulin-stimulated uptake of aminoisobutyrate. The conditions of cell isolation and measurement of insulin binding and AIB uptake are described in Methods. The concentrations of insulin used are 0.6 (tracer), 5.6, 50.6, 500.6, and 5000.6 (nonspecific binding) $\mathrm{ng} / \mathrm{ml}$. The data represent the mean $\pm S E$ of triplicate plates from three separate experiments in each group.

min in control and dexamethasone-treated cells respectively), the maximal insulin-stimulated rate of uptake is significantly decreased in the treated cells (Fig. $6 P<0.05$ ). This is true whether expressed as a percentage or absolute response.

Because cells treated with dexamethasone are resistant to at least 1 parameter of insulin action, AIB uptake, we next evaluated whether these cells might be resistant to another action of insulin: the ability of insulin to down regulate its receptor. Fig. 7 illustrates that dexamethasone-treated cells are resistant to the ability of insulin to regulate its receptor. In these three experiments control cells incubated in the presence of insulin demonstrated a $52 \pm 3 \%$ decrease in insulin binding. These data are consistent with previous data from our laboratory, which demonstrated a 46-61\% decrease in specific insulin binding to primary cultures of hepatocytes incubated with insulin and several agents that mimic insulin action (6).

\section{DISCUSSION}

Our studies were undertaken because previous work from our laboratory indicated that down regulation of the insulin receptor might be one of the many biological responses of a cell to insulin (6). If this were true, a cell that is resistant to the action of insulin might have a normal number of insulin receptors in the presence of elevated circulating levels of insulin. There are several altered metabolic states in which this situation exists including some obese people (11-13), older, obese rats $(5,20)$, Zucher rats (21), diabetic Pima Indians (18), some patients with lipoatrophic diabetes mellitus (15), leprechanism (19), myotonic dystrophy (14), uremia (17), and spinal cord injury (16). To further evaluate the relationships between insulin resistance and insulin binding, we chose the in vivo and in vitro models of glucocorticoid excess in freshly isolated and primary cultures of rat hepatocytes. This insulin-resistant state and tissue were chosen because glucocorticoid excess is a frequently observed clinical problem, the liver is an important target organ for

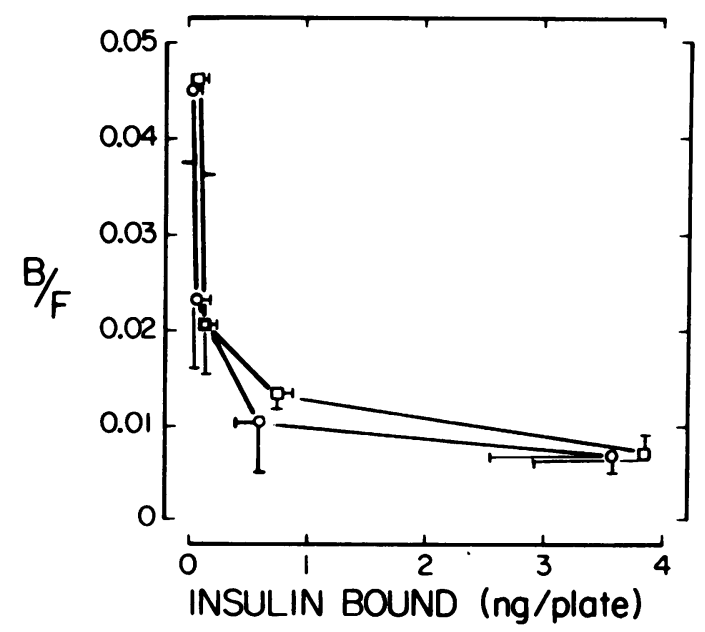

Figure 7 Scatchard analyses of the insulin binding data in primary cultures of rat hepatocytes exposed to dexamethasone, $0.1 \mu \mathrm{M}$, for $24 \mathrm{~h}(\mathrm{O}$, dexamethasone, $0.1 \mu \mathrm{M})(\square$, dexamethasone, $0.1 \mu \mathrm{M}+$ insulin, $0.1 \mu \mathrm{M})$. The conditions of cell isolation and culture and measurement of insulin binding are described in Methods and the legend to Fig. 6. The data represent the mean $\pm S E$ of triplicate plates from three separate experiments in each group. 
glucocorticoid hormones (32-34), and the effects of glucocorticoids on the relationships between insulin action, binding, and degradation in the liver have not been studied. Previous studies have evaluated insulin binding alone in isolated hepatocytes (35) and liver plasma membranes $(36,37)$.

Our data demonstrate that dexamethasone treatment for both 1- and 4-wk results in hyperinsulinemia in the presence of normal serum glucose levels, a condition suggestive of insulin resistance. After $1 \mathrm{wk}$ of in vivo treatment with dexamethasone, freshly isolated hepatocytes are slightly but insignificantly insensitive and normally responsive to insulin. These cells bind less insulin due to a decrease in both insulin receptor number and affinity. Because alterations in insulin sensitivity but not responsiveness are the expected occurance with changes in receptor number and affinity, these results might be anticipated. Insulin degradation, however, is increased while the relationship between insulin binding and degradation is preserved. After 4 wk of in vivo treatment with dexamethasone, freshly isolated hepatocytes are markedly resistant to insulin, yet insulin binding and degradation have returned to the levels observed in hepatocytes from control animals. Thus, these cells are resistant to insulin despite normal insulin binding, which indicates a postbinding defect(s) in insulin action. Furthermore, down regulation of the insulin receptor was observed only when the hepatocytes were responsive to insulin, i.e., after 1 wk of treatment. This implies that hepatocytes that are responsive to insulin will down regulate in the presence of hyperinsulinemia and that if a cell becomes resistant to insulin, receptor number can return to normal, i.e., the cell is resistant to the ability of insulin to down regulate. It is unlikely that the changes in insulin binding observed are due to dexamethasone itself because insulin binding returned to normal levels after $4 \mathrm{wk}$ of treatment, at which time dexamethasone action was still present as manifested by a worsening of the insulin-resistant state and the continued increase in basal AIB uptake. This latter effect is thought to be due to a synergistic effect of glucagon and glucocorticoids (38). Also, the addition of dexamethasone to primary cultures of rat hepatocytes had little effect on insulin binding but led to insulin resistance and an inability of insulin to down regulate its receptor.

Olefsky et al. (35) studied insulin binding in hepatocytes and adipocytes from rats receiving dexamethasone for $6 \mathrm{~d}$ and $3 \mathrm{wk}$ at a dosage four times lower than the one used in this study. These authors observed partial recovery of insulin binding in hepatocytes and almost complete recovery in adipocytes after $3 \mathrm{wk}$ of treatment and postulated that the return of insulin binding was related to an improvement in insulin resistance. This explanation is not supported by our data.
In fact, under the conditions of our studies, insulin resistance in hepatocytes worsens with prolonged dexamethasone treatment.

With regard to insulin degradation, because we (26) and others (31) have demonstrated a close correlation between insulin binding and degradation in hepatocytes from normal rats, it might be expected that hepatocytes from animals treated with dexamethasone for $1 \mathrm{wk}$ would degrade less insulin. These hepatocytes, however, degrade more insulin. This suggests that degradation too can be regulated by postbinding mechanisms. Indeed hepatic insulin-degrading activity is decreased in liver homogenates (39-42) and liver slices (42) from starved (39) and diabetic (40-42) animals. Similar findings have been reported for hepatic levels of glutathione-insulin transhydrogenase (43). Freshly isolated hepatocytes from these animals also degrade less yet bind the same or increased quantities of insulin (5). Thus, it appears that although insulin binding and degradation may be linked, it is likely that the response of the effector-degradative system(s) after binding is also regulated, perhaps independently of the receptor complex. Such regulation would explain why the normal relationship between insulin binding and degradation persists in hepatocytes from group I Dex animals but at an increased rate of degradation. It has been suggested (42) that the liver has an autoregulatory mechanism for the control of insulin degradation, which is governed at least partially by the level of insulin in the plasma. Although the mechanism by which the hyperinsulinemia present in group I Dex animals may lead to a faster rate of insulin degradation is unknown, one possible mechanism is by stimulation of the quantity or activity of degradative enzymes. With decreased binding, the quantity of insulin bound and internalized might be less, but the rate of degradation of internalized insulin might be greater. This situation would not alter the relationship between insulin binding and degradation but would result in more degradation for any amount of hormone bound (Figs. $4,5)$. An alternative explanation is that the activity or quantity of degradative enzymes is unaltered but the rate of internalization of insulin is enhanced disproportionately to the decrease in receptor number. Because insulin degradation returned to normal when the hepatocytes became resistant to insulin with regard to AIB uptake (group II Dex) it is likely that this regulatory mechanism also requires that the cell be responsive to insulin.

The interpretation of in vivo studies is complicated by the many changes that occur in the hormonal and substrate milieu. To avoid these complicating factors and to further assess the role of dexamethasone itself in the changes in insulin binding, action, and degradation in dexamethasone-treated animals, we exposed 
primary cultures of rat hepatocytes from normal rats to dexamethasone, $0.1 \mu \mathrm{M}$, for $24 \mathrm{~h}$. Under these conditions insulin binding at high concentrations of insulin was increased by dexamethasone treatment (Fig. 6). These findings suggest that the decrease in insulin binding observed in hepatocytes from rats treated with dexamethasone for $1 \mathrm{wk}$ is due to the induced hyperinsulinemia and not the dexamethasone itself. Indeed, it is possible that the maintenance of insulin receptor number may be one of the many anabolic functions of glucocorticoids in the liver. Dexamethasone did not affect the basal rate of amino acid uptake in cultured hepatocytes. This is consistent with previous studies by Kletzien et al. (38) who demonstrated in the same cell system that dexamethasone has a synergestic effect with glucagon but by itself does not affect AIB uptake. In our studies dexamethasone did, however, render the primary cultures of hepatocytes resistant to insulin with regard to AIB uptake (Fig. 6). These cells, therefore, provided the opportunity to evaluate in vitro whether insulin can down regulate its receptor in an insulin-resistant cell. While parallel cultures incubated with insulin, $0.1 \mu \mathrm{M}$, in the absence of dexamethasone had a $52 \%$ decrease in insulin binding, cells incubated with dexamethasone, $0.1 \mu \mathrm{M}$, plus insulin, $0.1 \mu \mathrm{M}$, were resistant to the ability of insulin to down regulate its receptor (Fig. 7). These data support the conclusion that the return to control levels of insulin binding in hepatocytes from animals treated with dexamethasone for $4 \mathrm{wk}$ is most likely due to the induction by dexamethasone of resistance to the ability of insulin to down regulate its receptor.

These studies emphasize the importance of post receptor events in the modulation of insulin binding, action, and degradation in the liver and support the hypothesis that down regulation of the hepatocyte insulin receptor is one of the many biological actions of insulin. It is important to note, however, that in a given metabolic state one or more tissues may be resistant $(5,44)$ to insulin but others may be responsive $(5,45)$. Likewise, one tissue may be resistant to one hormone (5) but not another (46). It is possible, therefore, that different tissues in the same metabolic state or the same tissue in different metabolic states may respond differently to the ability of insulin to down regulate its receptor. Those tissues evaluated from insulin-resistant states with hyperinsulinemia, and normal numbers of insulin receptors (11-21) may be examples of resistance to insulin with regard to down regulation of its receptor, whereas those with decreased numbers of receptors (1-3) may be examples of responsiveness to this action of the hormone.

\section{ACKNOWLEDGMENTS}

We thank Dr. J. N. Livingston for his critical review of the manuscript. This work was supported by National Institutes of Health grant AM 20948 and a grant from the Juvenile Diabetes Foundation. Dr. Caro is the recipient of a Juvenile Diabetes Foundation fellowship and Dr. Amatruda of a National Institutes of Health Research Career Development award AM 00366

\section{REFERENCES}

1. Roth, J., C. R. Kahn, M. A. Lesniak, P. Gorden, P DeMeyts, K. Megyesi, D. M. Neville, Jr., J. R. Gavin III, A. H. Soll, P. Freychet, I. D. Goldfine, R. S. Bar, and J. A. Archer. 1975. Receptors for insulin, NSILA-s and growth hormone: applications to disease states in man. Recent Prog. Horm. Res. 31: 95-126.

2. Olefsky, J. M. 1976. Decreased insulin binding to adipocytes and circulating monocytes from obese subjects J. Clin. Invest. 57: 1165-1172.

3. Bar, R. S., P. Gorden, J. Roth, C. R. Kahn, and P DeMeyts. 1976. Fluctuations in the affinity and concentration of insulin receptors on circulating monocytes of obese patients. J. Clin. Invest. 58: 1123-1135.

4. Kahn, C. R., D. M. Neville, Jr., and J. Roth. 1973. Insulin receptor interaction in the obese-hyperglycemic mouse. A model of insulin resistance. J. Biol. Chem. 248: 244250.

5. Cech, J. M., R. B. Freeman, Jr., J. F. Caro, and J. M Amatruda. 1980. Insulin action and binding in isolated hepatocytes from fasted, streptozotocin-diabetic, and older, spontaneously obese rats. Biochem. J. 188: 839845.

6. Caro, J. F., and J. M. Amatruda. 1980. Insulin receptors in hepatocytes: postreceptor events mediate down regulation. Science (Wash., D. C.). 210: 1029-1031

7. Gavin, J. R. III, J. Roth, D. M. Neville, Jr., P. DeMeyts, and D. N. Buell. 1974. Insulin-dependent regulation of insulin receptor concentrations: a direct demonstration in cell culture. Proc. Natl. Acad. Sci. U. S. A. 71: 8488.

8. Blackard, W. G., P. S. Guzelian, and M. E. Small. 1978 Down regulation of insulin receptors in primary cultures of adult rat hepatocytes in monolayer Endocrinology. 103: $548-553$.

9. Livingston, J. N., B. J. Purvis, and D. H. Lockwood 1978. Insulin-dependent regulation of the insulin-sensitivity of adipocytes. Nature (Lond.). 273: 394-396.

10. Mott, D. M., B. V. Howard, and P. H. Bennett. 1979. Stoichiometric binding and regulation of insulin receptors on human diploid fibroblasts using physiologic insulin levels. J. Biol. Chem. 254: 8762-8767.

11. Amatruda, J. M., J. N. Livingston, and D. H. Lockwood. 1975. Insulin receptor: role in the resistance of human obesity to insulin. Science (Wash., D. C.). 188: 264-266.

12. Misbin, R. I., J. P. O'Leary, and A. Pulkkinen. 1979. Insulin receptor in obesity: a reassessment. Science (Wash., D. C.). 205: 1003-1004.

13. Smith, V., and M. DiGirolamo. 1980. Binding of insulin to human adipocytes in relation to age, relative body weight and fat cell size. Clin. Res. 28: 406A.

14. Kobayashi, M., J. C. Meek, and E. Streib. 1977. The insulin receptor in myotonic dystrophy. J. Clin. Endocrinol. Metab. 45: 821-824.

15. Rosenbloom, A. L., S. Goldstein, and C. C. Yip. 1977. Normal insulin binding to cultured fibroblasts from patients with lipoatrophic diabetes. J. Clin. Endocrinol. Metab. 44: 803-806.

16. Duckworth, W. C., S. S. Solomon, P. Jallepalli, C. Heckemeyer, J. Finnern, and A. Powers. 1980. Glucose in- 
tolerance due to insulin resistance in patients with spinal cord injuries. Diabetes. 29: 906-910.

17. DeFronzo, R. A. 1978. Pathogenesis of glucose intolerance in uremia. Metab. Clin. Exp. 27: 1866-1880.

18. Huecksteadt, T., F Kosmakos, and D. Mott. 1980. Insulin binding to erythrocytes and monocytes from Pima Indians with various degrees of hyperinsulinemia. Diabetes. 29: 39A.

19. Kobayashi, M., J. M. Olefsky, J. Elders, M. E. Mako, B. D. Given, H. K. Schedwie, R. H. Fiser, R. L. Hintz, J. A. Horner, and A. Rubenstein. 1978. Insulin resistance due to a defect distal to the insulin receptor: demonstration in a patient with leprechanism. Proc. Natl. Acad. Sci. U. S. A. 75: 3469-3473.

20. Livingston, J. N., P. Cuatrecasas, and D. H. Lockwood. 1972. Insulin insensitivity of large fat cells. Science (Wash., D. C.). 177: 626-628.

21. Broer, Y., P. Freychet, and G. Rosselin. 1977. Insulin and glucagon interactions in the genetically obese Zucker rat: studies of hormone binding and glucagonstimulated cyclic AMP levels in isolated hepatocytes. Endocrinology. 101: 236-249.

22. Kosmakos, F. C., and J. Roth. 1980. Insulin induced loss of the insulin receptor in $1 \mathrm{M}-9$ lymphocytes. A biological process mediated through the insulin receptor. J. Biol. Chem. 255: 9860-9869.

23. Draznin, B., C. C. Solomons, D. R. Toothaker, and K. E. Sussman. 1981. Energy-dependent steps in insulinhepatocyte interaction. Endocrinology. 108: 8-17.

24. Cuatrecasas, P. 1971. Insulin-receptor interactions in adipose tissue cells: direct measurement and properties. Proc. Natl. Acad. Sci. U. S. A. 68: 1264-1268.

25. Caro, J. F., and J. M. Amatruda. 1981. Evidence for the modulation of insulin action and degradation independently of insulin binding. Am. J. Physiol. 240: E325E332.

26. Caro, J. F., and J. M. Amatruda. 1980. Functional relationships between insulin binding, action, and degradation: a reassessment. J. Biol. Chem. 255: 10052-10055.

27. Cuatrecasas, P. 1972. Isolation of the insulin receptor of liver and fat-cell membranes. Proc. Natl. Acad. Sci. U. S. A. 69: 318-322.

28. LeCam, A., and P. Freychet. 1978. Effect of insulin on amino acid transport in isolated rat hepatocytes. Diabetologia. 15: 117-123.

29. DeMeyts, P., and J. Roth. 1975. Cooperativity in ligand binding: a new graphic analysis. Biochem. Biophys. Res. Commun. 66: 1118-1126.

30. Gorden, P., J-L. Carpentier, P. Freychet, and L. Orci. 1980. Internalization of peptide hormones: mechanism, intracellular localization and significance. Diabetologica. 18: 263-274.

31. Terris, S., and D. F. Steiner. 1975. Binding and degradation of ${ }^{125}$ I-insulin by rat hepatocytes. J. Biol. Chem. 250: 8389-8398.
32. Diamant, S., and E. Shafrir. 1975. Modulation of the activity of insulin-dependent enzymes of lipogenesis by glucocorticoids. Eur. J. Biochem. 53: 541-546.

33. Mersmann, H. J., and H. L. Segal. 1969. Glucocorticoid control of the liver, glycogen synthetase-activating system. J. Biol. Chem. 244: 1701-1704.

34. Gelehrter, T. D., J. R. Emanuel, C. J. Spencer. 1972 Induction of tyrosine aminotransferase by dexamethasone, insulin and serum. J. Biol. Chem. 247: 6197-6203.

35. Olfesky, J. M., J. Johnson, F. Liu, P. Jen, and G. M. Reaven. 1975. The effects of acute and chronic dexamethasone administration on insulin binding to isolated rat hepatocytes and adipocytes. Metabolism. 24: 517527.

36. Goldfine, I. D., C. R. Kahn, D. M. Neville, Jr., J. Roth, M. M. Garrison, and R. W. Bates. 1973. Decreased binding of insulin to its receptors in rats with hormone induced insulin resistance. Biochem. Biophys. Res. Commun. 53: 852-857.

37. Kahn, C. R., I. D. Goldfine, D. M. Neville, Jr., and P DeMeyts. 1978. Alterations in insulin binding induced by changes in vivo in the levels of glucocorticoids and growth hormone. Endocrinology. 103: 1059-1066.

38. Kletzien, R. F., M. W. Pariza, J. E. Becker, and V. R. Potter. 1976. Hormonal regulation of amino acid transport and gluconeogenesis in primary cultures of adult rat liver parenchymal cells. J. Cell Physiol. 89: 641-646.

39. Broh-Kahn, R. H., and I. A. Mirsky. 1949. The inactivation of insulin by tissue extracts. II. The effect of fasting on the insulinase content of rat liver. Arch. Biochem. Biophys. 20: 10-14.

40. Morgan, C. R., and H. J. Wiesman. 1968. Liver insulinase activity in insulin deficient rats. Proc. Soc. Exp. Biol. Med. 127: 763-765.

41. Morgan, C. R., J. Spahn, V. Frazier, and S. Fleitz. 1968. Insulin as a possible inducer of the biosynthesis of rat liver insulinase. Proc. Soc. Exp. Biol. Med. 128: 795-797.

42. Uete, T., and H. Tsuchikura. 1972. Autoregulatory system of insulin degradation in liver. I. Decreased ${ }^{131} \mathrm{I}-$ insulin degradation in the liver of insulin deficient rats J. Biochem. (Tokyo). 72: 157-163.

43. Varandani, P. T. 1974. Insulin degradation. VI. Feedback control by insulin of liver glutathione-insulin transhydrogenase in rat. Diabetes. 23: 117-125.

44. Wieringa, T., and H. M. J. Krans. 1978. Reduced glucose transport and increased binding of insulin in adipocytes from diabetic and fasted rats. Biochem. Biophys. Acta. 538: 563-570.

45. LeMarchand-Brustel, Y., and P. Freychet. 1979. Effect of fasting and streptozotocin diabetes on insulin binding and action in the isolated mouse soleus muscle. J. Clin. Invest. 64: 1505-1515.

46. Caro, J. F., and J. M. Amatruda. 1980. The effect of fasting on glucagon binding and action in isolated rat hepatocytes. Metabolism. 29: 732-738. 